УДК: 579.266 .4

O. Maslovska, S. Hnatush

Ivan Franko National University of Lviv 4, Hrushevskyi St.,

Lviv, 79005, Ukraine, e-mail: gnatuk88@ukr.net

\title{
OXIDATIVE MODIFICATION OF PROTEINS AND SPECIFIC SUPEROXIDE DISMUASE ACTIVITY OF DESULFUROMONAS ACETOXIDANS IMV B-7384 BACTERIA UNDER THE INFLUENCE OF FERRIC CITRATE
}

\begin{abstract}
Aim. Investigation of oxidative modification of proteins and specific superoxide dismutase activity of Desulfuromonas acetoxidans IMV B-7384 bacteria under the influence of ferric citrate. Methods. Generation of protein carbonyl groups (CG) were determined in reaction with 2,4-dinitrophenylhydrazine. Specific superoxide dismutase activity was measured by the ability of enzyme to inhibit autoxidation of quercetin at $\mathrm{pH} 10$ in the presence of tetramethylethylenediamine. Results. The content of protein $C G$ under the influence of ferric citrate changed in dependence of duration of bacterial cultivation. Under the influence of all investigated concentrations of ferric citrate on second and third days of cultivation no significant increase of protein CG in comparison with control sample was observed. The increase of content of protein CG by 2-4 times under the influence of metal salt was reached on the fourth day of cultivation. Addition of ferric citrate caused substantial enhancing of specific SOD activity. Under the influence of all investigated concentrations of ferric citrate specific SOD activity increased with enhancing of duration of cultivation. Conclusions. Accumulation of significant concentrations of CG in D. acetoxidans IMV-B7384 proteins under the influence of ferric citrate indicates free radical mechanism of damage of cell proteins. Under these conditions neutralization of reactive oxygen species in D. acetoxidans IMV-B7384 bacteria is evidently made by the enzymes of antioxidative defense system, including SOD.
\end{abstract}

Key words: superoxide dismutase, oxidative modification of proteins, ferric citrate, Desulfuromonas acetoxidans.

Desulfuromonas acetoxidans is one of the first microorganisms which can receive energy needed for growth by the complete oxidation of organic compounds with simultaneous Fe (III) - and Mn (IV) - reduction [5]. The capability of D. acetoxidans to support Fe (III) - and Mn (IV) - reduction with simultaneous oxidation of organic compounds causes its favourableness in practical application since it could be used for creation of biotechnological methodologies for treatment of wastewater, which is polluted with heavy metals and organic compounds. Also Fe (III) - and Mn (IV) dissimilative reduction is the basis for exoelectrogenic activity of described bacteria 
which is highly favorable for microbial fuel cell construction [11]. Functional necessity of ferric ions as a factor playing the significant role in redox processes of the range of biochemical reactions is indisputable. Although ferric ions also possesses biologically dangerous properties since they catalyze generation of reactive oxygen species (ROS). Toxicity of ferric ions is based on Haber-Weiss and Fenton reactions [1]. Recently lipid peroxidation is considered as one of the main reasons of cell damage and death under the influence of ROS [3]. Equally significant violations are appeared under the oxidative modification of proteins (OMP). Changes in their hydrophobicity, isoelectric point and thermal stability, increased sensitivity to proteolysis and lost enzymes activity could be observed under OMP [7]. It was shown recently that modification of protein molecules under the influence of ROS can be resulted in appearance of additional carbonyl groups $(\mathrm{CG})$ in protein molecules. The content of CG in protein molecules mostly can be detected by reaction with 2,4-dinitrophenylhydrazine [9]. Aerobic and facultative anaerobic microorganisms possess effective complex of defensive enzymatic and non enzymatic systems of ROS destruction. They synthesize enzymes of DNA reparation (endonuclease III and endonuclease IV produced by Escherichia coli) and regulators of defense against oxidative stress. Similar mechanisms of antioxidative defense in anaerobic microorganisms have not been studied enough $[1,2]$. Usually oxidative stress in anaerobic microorganisms is caused by the influence of superoxide anion radical $\left(\mathrm{O}_{2}^{-}\right)$. As a result superoxide dismutase (SOD) is one of the crucial enzymes of antioxidative defense [2]. The processes of OMP and activity of antioxidant system, especially SOD activity in the cells of anaerobic microorganisms at the influence of heavy metals is not enough investigated. Investigation of defense mechanisms of $D$. acetoxidans bacteria under stress conditions such as gradual increasing of heavy metals concentration is crucial for understanding the mechanisms of bacterial metabolism regulation during the process of wastewater treatment. Thus, the aim of our work was to investigate the oxidative modification of proteins and specific activity of superoxide dismutase of D. acetoxidans IMV B-7384 bacteria under the influence of various concentrations of ferric citrate.

\section{Materials and methods}

The object of investigations was Desulfuromonas acetoxidans IMV B-7384 bacterium. Bacteria were cultivated in the modified Postgaite $\mathrm{C}$ medium for four days [10]. Sodium fumarate $(6 \mathrm{~g} / \mathrm{l})$ was added as electron donor and its acceptor. Ferric citrate was added into the growth medium in concentration 10-20 mM. It was shown that these concentrations of ferric citrate caused decreasing of biomass by $20-50 \%$ [8]. Metal salt was not added into the control. After the second, third and fourth day of bacterial growth cells were disintegrated on the ultrasonic homogenizer at $22 \mathrm{kHz}$ at $4{ }^{\circ} \mathrm{C}$ and cell-free extracts were obtained [8]. Protein concentration in cell-free extract was determined by Lowry method [6]. Appearance of additional carbonyl groups in the proteins was determined by the method indicated in [7]. Specific SOD activity was determined as described in [7]. Statistical calculation of results was carried out by application of the Origin and Excel programs [4] The crucial statistical 
indexes were calculated on the basis of direct data, such as arithmetical mean (M) and standard deviation of arithmetical mean (m). Student coefficient was calculated for the estimation of validity of difference between statistical characteristics of five alternative blocks of data. The difference was claimed to be valid under the index of validity $\mathrm{P}>0.95$.

\section{Results and its discussion}

The highest content of CG in proteins of $D$. acetoxidans IMV B-7384 bacteria cultivated in the medium without ferric citrate was observed on the third day of growth (fig. 1). Continuation of cultivation time up to four days caused the decreasing of CG content. The CG content in proteins changed dependently on time of bacterial cultivation under the influence of ferric citrate. Slight increasing of CG content in bacterial proteins was observed on the second and third day of $D$. acetoxidans IMV B-7384 growth under the influence of all investigated concentrations of ferric citrate in comparison with control.

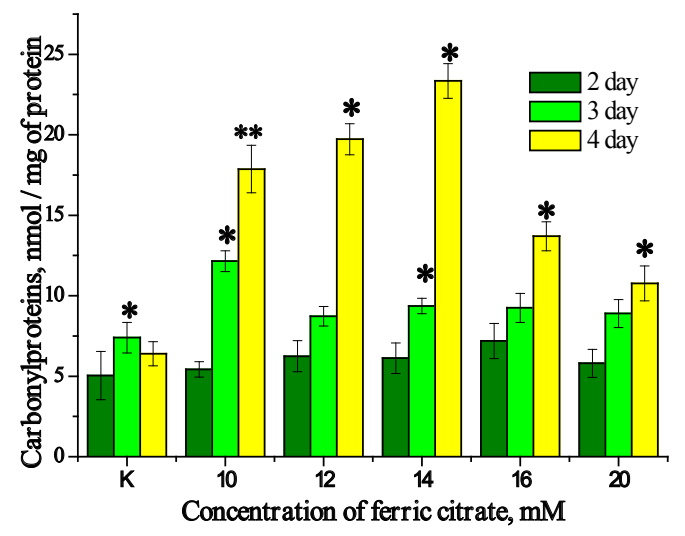

Fig. 1. The content of additional CG in proteins of $D$. acetoxidans IMV B-7384 bacteria under the influence of ferric citrate

( $\mathrm{K}-$ control; $* \mathrm{p} \geq 0.95, \mathrm{n}=5 ; * *-\mathrm{p} \geq 0.99, \mathrm{n}=5$ - in comparison with control)

Significant increasing of carbonyl proteins under the influence of metal salt was observed on the fourth day of cultivation. Addition of ferric citrate in concentrations 10,12 and $14 \mathrm{mM}$ on the fourth day of cultivation caused enlargement of content of additional $\mathrm{CG}$ in proteins by $2.6 ; 3$ and 3.5 times, respectively.

The content of CG in bacterial proteins also changed dependently on concentration of metal salt in cultural medium. Under the addition of ferric citrate in concentrations $10-14 \mathrm{mM}$ the content of CG in proteins significantly increased on the fourth day of bacterial cultivation comparing with control. The raising of metal salt concentration up to $20 \mathrm{mM}$ caused the decreased content of CG in comparison with content of CG in proteins under the influence of $14 \mathrm{mM}$ of ferric citrate but it was higher than in control. In our previous studies it was shown that addition of ferric citrate into cultural medium of $D$. acetoxidans IMV B-7384 led to the increasing 
content of lipid hydroperoxides, conjugated dienes and thiobarbituric reactive substances [8]. Accumulation of significant amounts of products of lipid peroxidation and additional CG in proteins in the cells of D. acetoxidans IMV B-7384 bacteria under the influence of ferric citrate confirms the free radical mechanism of oxidation of polyunsaturated fatty acids and cell proteins.

Antioxidative defense system supports cell protection against destructive influence of reactive oxygen species. SOD, catalase, peroxidase and oxidase provide the first stage of bacterial cell protection against reactive oxygen species [1]. Specific SOD activity changed dependently on growth phase of $D$. acetoxidans IMV B-7384 bacteria grown on the cultural medium without addition of ferric citrate. Activity of enzyme increased with continuation of duration of cultivation (fig. 2).

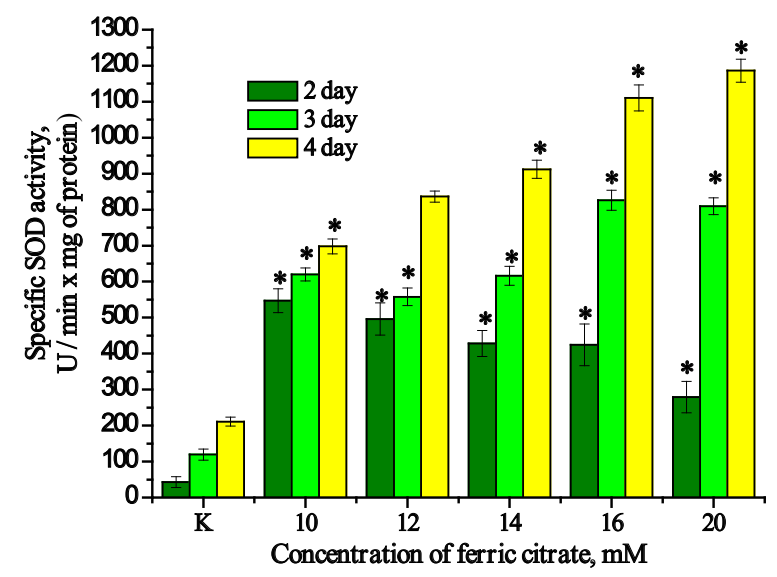

Fig. 2. Specific SOD activity of $D$. acetoxidans IMV B-7384 bacteria under the influence of ferric citrate

( $\mathrm{K}-$ control; * $-\mathrm{p} \geq 0,95$ - compared with control)

Addition of ferric citrate caused significant increasing of specific enzyme activity. Specific SOD activity was also increased by 12 times on the second day of cultivation under the influence of $10 \mathrm{mM}$ of ferric citrate in comparison with control. Significant raising specific SOD activity was observed under the influence of all investigated concentrations of ferric citrate. Specific SOD activity increased with continuation of duration of cultivation under the influence of investigated metal salt (fig. 2). On the second day of growth specific SOD activity equaled $546.8 \pm 33.25 \mathrm{U} / \mathrm{min} \times \mathrm{mg}$ of protein at the influence of $10 \mathrm{mM}$ of ferric citrate. Increasing of concentration of metal salt up to $20 \mathrm{mM}$ led to decreasing of specific enzyme activity. On the third day of cultivation enzyme activity remained at the level 580-605 U/min $\times \mathrm{mg}$ of protein under the addition of $10-14 \mathrm{mM}$ of investigated metal salt. Addition of 16 and $20 \mathrm{mM}$ of ferric citrate into the growth medium caused increasing of specific SOD activity in comparison with the influence of $10-14 \mathrm{mM}$ of metal salt. On the fourth day of cultivation specific enzyme activity increased with enlarging of ferric 
citrate concentration. Maximal specific SOD activity was observed on the fourth day of cultivation under the addition of $20 \mathrm{mM}$ of ferric citrate.

The influence of several transition metals on specific SOD activity of D. acetoxidans under its growth in Postgaite $\mathrm{C}$ medium that contains lactic acid as the electron donor and elemental sulfur as the electron acceptor has been previously determined [12]. It was shown that addition of various concentrations of ferric (III) chloride $(0.5-2.0 \mathrm{mM})$ caused significant increase of specific enzyme activity starting from the second day of cultivation. Specific SOD activity decreased with the increasing of duration of cultivation to four days under the influence of all investigated ferric (III) chloride concentrations.

Changing conditions and growing bacteria in the medium with addition of sodium fumarate and without sulfur we did not observe hydrogen sulfide formation. Under this conditions metal ions are not precipitated in the forms of insoluble metal sulfides. Using ferric citrate as a component of the growing medium maintains the presenc of $\mathrm{Fe}^{3+}$ ions. It is known that $\mathrm{Fe}^{3+}$ ions could stimulate formation in cells of microorganisms ROS [1].

The addition of ferric citrate in concentrations $10-20 \mathrm{mM}$ caused the increase of additional carbonyl groups in proteins of D. acetoxidans IMV B-7384 bacteria by 1.5-3.5 times in comparison with control. Under those conditions specific SOD activity increased by 1.5-3.5 times. Thus, addition of ferric citrate into the growth medium of $D$. acetoxidans IMV B-7384 led to formation of active oxygen species that was confirmed by the appearance of additional carbonyl groups in proteins of bacteria. Superoxide dismutase is involved in neutralization of free radicals of oxygen under the influence of ferric citrate in D. acetoxidans IMV B-7384 cells.

\title{
О.Д. Масловська, С.О. Гнатуш
}

Львівський національний університет імені Івана Франка, вул. Грушевського, 4, Львів, 79005, Україна, e-mail: gnatuk88@ukr.net

\section{ОКИСНА МОДИФІКАЦІЯ БІЛКІВ ТА ПИТОМА АКТИВНІСТЬ СУПЕРОКСИДДИСМУТАЗИ БАКТЕРІЙ DESULFUROMONAS ACETOXIDANS IMВ В-7384 ЗА ВПЛИВУ ФЕРУМ ЦИТРАТУ}

\begin{abstract}
Реферат
Мета. Дослідити окисну модифікацію білків та питому активність супероксиддисмутази бактерій Desulfuromonas acetoxidans IMB B-7384 за впливу різних кониентрацій ферум иитрату. Методи. Уворення додаткових карбонільних груп (КГ) у бічних ланцююгах амінокислот визначали у реакиії 3 2,4-динітрофенілгідразином. Питому активність супероксиддисмутази (СОД) визначали за здатністю ферменту інгібувати автоокиснення квериетину при рН 10 у присутності тетраметилетилендиаміну. Результати. Вміст КГ у білках за впливу ферум циитрату змінювався залежно від часу культивування бактерій. $3 а$
\end{abstract}


усіх досліджених концентрацій ферум ичитрату на другу та третю добу культивування спостерігали незначне зростання вмісту КГ у білках бактерій, порівняно з вмістом цихх груп у контрольному зразку. Зростання вмісту КГ у білках у 2-4 рази за впливу солі металу зафіксовано на четверту добу культивування. Внесення ферум циттрату зумовлювало суттєве зростання питомої активності СОД. За впливу усіх досліджених концеентрацій ферум ичитрату питома активність СОД зростала зі збільшенням часу культивування. Висновки. Нагромадження у клітинах значних кількостей додаткових КГ у білках бактерій D. acetoxidans IMB-B7384 за впливу ферум цчитрату свідчить про вільнорадикальний механізм пошкодження клітинних білків. За циих умов знешкодження активних метаболітів оксигену у клітинах D. aсеtoxidans IMB-B7384 здійснюють, очевидно, ферменти системи антиоксидантного захисту, зокрема СОД.

Ключові слова: супероксиддисмутаза, окисна модифікація протеїнів, ферум ųumpam, Desulfuromonas acetoxidans.

\section{О.Д. Масловская, С.А. Гнатуш}

Львовский национальный университет имени Ивана Франко, ул. Грушевского, 4, Львов 79005, Украина, e-mail: gnatuk88@ukr.net

\section{ОКИСЛИТЕЛЬНАЯ МОДИФИКАЦИЯ БЕЛКОВ И УДЕЛЬНАЯ АКТИВНОСТЬ СУПЕРОКСИДЛИСМУТАЗЫ БАКТЕРИЙ DESULFUROMONAS ACETOXIDANS ИМВ В-7384 ПРИ ВОЗДЕЙСТВИИ ЦИТРАТА ЖЕЛЕЗА}

\section{Реферат}

Цель. Исследовать окислительную модификацию белков и удельную активность супероксиддисмутазы бактерий Desulfuromonas acetoxidans ИМВ В-7384 при воздействии различных концентраций изитрата железа. Методы. Образование дополнительных карбонильных групп (КГ) в боковых цепях аминокислот определяли в реакиии с 2,4-динитрофенилгидразином. Удельную активность супероксиддисмутазы (СОД) определяли по способности фермента ингибировать автоокиснення квериетина при рН 10 в присутствии тетраметилэтилендиамина. Результаты. Содержание КГ в белках при влиянии цุитрата железа менялось в зависимости от времени культивирования бактерий. При влиянии всех исследуемых концентраций ферум циттрата на вторые и третьи сутки культивирования наблюдали незначительное повышение содержания КГ в белках бактерий по сравнению с содержанием данных групп в контрольном образие. Рост содержания КГ в белках в 2-4 раза при влиянии соли металла зафиксировано на четвертые сутки культивирования. Внесение циитрата железа приводило к значительному росту удельной активности СОД. При влиянии всех исследованных концентраций циитрата железа удельная активность СОД возрастала с увеличением времени культивирования. Выводы. Накопление в клетках значительных количеств дополнительных КГ в белках бактерий D. acetoxidans ИМВ В-7384 при влиянии цитрата железа свидетельствует о свободнорадикальном механизме повреждения клеточных белков. В этих условиях обезврежи- 
вание активных метаболитов кислорода в клетках D. acetoxidans ИМВ В-7384 осуществляют, очевидно, ферменты системь антиоксидантной защитыл, в частности СОД.

Ключевые слова: супероксиддисмутаза, окислительная модификация протеинов, ичттрата железа, Desulfuromonas acetoxidans.

\section{LITERATURE}

1. Brioukhanov A., Netrusov A. Aerotolerance of strictly anaerobic microorganisms and factors of defense against oxidative stress: a review // Appl. Biochem. Microbiol. - 2007. - 43, № 6. - P. 635-652.

2. Fareleira P., Santos $B$. Response of a strict anaerobe to oxygen: survival strategies in Desulfovibrio gigas // Microbiol. - 2003. - 149. - P. 1513-1522.

3. Golovchak N., Tarnovs 'ka A., Kocjumbas G., Sanagurs 'kij D. Lipid peroxidation in living organisms. - L.: Ivan Franko national university of Lviv, 2012. - 250 p.

4. Lakin G. Biometrics. - M.: Vysshaja shkola, 1990. - 352 p.

5. Lovely D., Holmes D., Nevin K. Dissimilatory Fe (III) and Mn (IV) reduction // Advances in microbial physiol. - 2011. - 59, № 1. - P. 1-100.

6. Lowry O., Rosenbrough N, Farr L., Randall R. Protein measurement, with the Folin phenol reagent // J. Biol. Chem. - 1951. - 193. - P. 265-275.

7. Lushchak V., Bagnyukova T., Lushchak O. Indices of oxidative stress. 1. TBA-reactive substrates and carbonylproteins // Ukr. biochem. j. - 2004. - 76, № 3. - P. 136-141.

8. Maslovska O., Hnatush $S$. The intensity of lipid peroxidation and parameters of antioxidative defense system of Desulfuromonas acetoxidans IMV B-7384 under the influence of ferric (III) citrate // Visnyk of the Lviv University. Ser. Biol. - 2014. 64. - P. 270-278.

9. Semchyshyn H.M., Lushchak V.I. Oxidative stress and control of catalase activity in Escherichia coli // Ukr. biochem. j. - 2004. - 76, № 3. - P. 31-42.

10. Postgate J. The sulfate-reducing bacteria. - C.: Cambridge University Press, 1984. - 208 p.

11. Vasyliv O., Bilyy O., Ferensovich Ja., Hnatush S. Electric current generation by sulfur-reducing bacteria in microbial-anode fuel cell // Proceedings of the SPIE, 2012. - P. 84720Z-1-7.

12. Vasyliv O., Hnatush $S$. Influence of transition metal compounds on superoxide dismutase activity of sulfur reducing Desulfuromonas acetoxidans bacteria // Microbiol. J. - 2013. - 75, № 2. - P. 37-44.

Стаття надійшла до редакції 26.12.2014 p. 